\title{
The Location of Mucopolysaccharides on Ultrathin Sections of Bacteria by the Silver Methanamine Staining Technique
}

\author{
By P. D. WALKER AND J. SHORT \\ The Wellcome Research Laboratories, Beckenham, Kent, England
}

(Accepted for publication 28 February 1968)

SUMMARY

The silver methanamine technique was used to locate mucopolysaccharides in ultrathin sections of bacteria. Polysaccharides were located along the cell wall and developing cross-walls in young vegetative forms and along the developing cortex in sporulating bacilli. The results are discussed in relation to morphological and chemical studies.

\section{INTRODUCTION}

The details of sporulation and germination in bacteria have been extensively studied by the technique of ultrathin sectioning. Species studied include both those in the genus Bacillus (Young \& Fitz-James, 1959 $a, b$; 1962; Fitz-James, 1960; Ohye \& Murrell, 1962; Kawata, Inoue \& Takagi, 1963) and in the genus Clostridium (Hashimoto \& Naylor, I958; Takagi, Kawata \& Yamamoto, I960; Fitz-James, 1962). More recently electron-microscope studies have been combined with immunological and cytochemical studies to demonstrate the location of antigens (Thomson, Walker \& Hardy, I966; Walker, Baillie, Thomson \& Batty, I966; Walker, Thomson \& Baillie, I967a, $b$ ) and enzymes (van Iterson \& Leene, 1964a, $b$; Sedar \& Burde, 1965 $a, b$; Baillie, Thomson, Batty \& Walker, 1967) during various phases of growth.

Proteins and nucleic acids have been located on ultrathin sections of bacteria by observing the changes in structure produced following extraction of these components by digestion with specific enzymes (Granboulan \& Leduc, 1967). Although proteins could be digested by proteinases in ultrathin sections of osmium-treated cells (Monneron \& Bernhard, 1966), satisfactory digestion of nucleic acids with nucleases was only obtained after aldehyde fixation and the use of a water-soluble resin (Granboulan \& Leduc, 1967). Nermut (1967) attempted to stain ultrathin sections of Bacillus megaterium for polysaccharides using Ruthenium red, although the results were not very satisfactory. Various methods have been devised for staining ultrathin sections of animal tissues to demonstrate carbohydrates such as glycogen, mucopolysaccharides and glycoproteins. One of these, the silver methanamine technique, was first devised for conventional light microscopy (Gomori, 1946; Jones, 1957) but was later extended to the demonstration of polysaccharide-rich structures in tissues using the electron microscope (Churg, Mautner \& Grisham, 1958; De Martino \& Zamboni, 1967). In the present paper modifications of this technique are described for the staining of bacterial polysaccharides during phases of sporulation and germination. 


\section{METHODS}

Organisms. The following organisms were used: Clostridium bifermentans (Wellcome Research Laboratories collection) CNI617; $C$. botulinum type C CN4946; $C$. sporogenes (Leeds University Bacteriology Department collection) L 206; Bacillus cereus var. terminalis.

Sporulation. In the case of Clostridium bifermentans and $C$. sporogenes the deposit from $25 \mathrm{ml}$. of a $6 \mathrm{hr}$ sporulating culture in heart infusion broth (Difco) was fixed for $\mathrm{I} 8 \mathrm{hr}$ in the fixative of Kellenberger, Ryter \& Séchaud (I958). Similar deposits of sporulating bacteria of $C$. botulinum type $\mathrm{C}$ and Bacillus cereus were prepared from I $8 \mathrm{hr}$ cultures in Robertson meat broth and the sporulating medium of Young (I958), respectively.

Germination. Spore suspensions of Clostridium bifermentans and Bacillus cereus were heat-shocked at $65^{\circ}$ for $10 \mathrm{~min}$. and incubated in nutrient broth containing $5 \mathrm{~mm}$-L-alanine. Samples were removed after $5 \mathrm{~min}$. and $\mathrm{I} \mathrm{hr}$ for centrifugation and fixation.

Preparation of ultrathin sections. After fixation all specimens were dehydrated in ethanol and embedded in Maraglas (Freeman \& Spurlock, 1962). Sections were cut with an L.K.B. 'Ultratome' on to distilled water and transferred by means of a wire loop on to the various staining solutions. After the final rinse the sections were collected on 200-mesh formvar-coated grids and examined in a Philips EM 200 electron microscope at $60 \mathrm{kV}$.

Staining solutions and method of staining. The method used was essentially that of Marinozzi (I96I) as modified by Short (I968). To Io $\mathrm{ml} .0 .25 \%(\mathrm{w} / \mathrm{v}$ ) silver nitrate add $10 \mathrm{ml}$. absolute ethanol, $0.3 \mathrm{~g}$. methanamine and $10 \mathrm{ml}$. distilled water.

Method. Float the sections on to $0.5 \%$ periodic acid, to oxidize them, for $10-20 \mathrm{~min}$; wash in two changes of distilled water; transfer to the silver solution in a covered receptacle and leave for $2 \mathrm{hr}$ at room temperature (about $22^{\circ}$ ); wash thoroughly four or five times in distilled water; transfer to $0.5 \%$ sodium thiosulphate for I-2 min.; wash in distilled water; mount on grids.

\section{RESULTS}

The results of staining ultrathin sections of Clostridium bifermentans with silver are shown in Pls. I, 2 and 3; in each case similar sections are compared before and after treatment. It can be seen in Pl. I, fig. I that silver deposits were arranged along the cell wall of the young vegetative form and along the developing cross-wall, with little staining of the cytoplasm; there was considerable difference in contrast between the oxidized and unoxidized sections. Staining of the developing spore is shown in Pl. 2, fig. 2. Both the vegetative cell wall and the developing cortex are stained with silver grains. In the section of germinating spores, shown in Pl. 3, fig. 3, only the cell wall of the emerging vegetative form is stained.

A similar picture is shown for sporulating forms of Clostridium botulinum type $\mathrm{C}$ (Pl. 4, figs. 4, 5) and C. sporogenes (Pl. 4, fig. 6). In both cases the cell wall and developing cortex, but not the spore coat, were stained by silver deposits. Very similar results were found both in sporulating forms and in germinating spores of Bacillus cereus. In freshly germinated spores of $B$. cereus only the region of the disintegrating cortex and developing vegetative cell wall was stained (Pl. 4, fig. 7). 


\section{DISCUSSION}

Staining of carbohydrates results from the reduction of the silver solution by free aldehyde groups released from the mucopolysaccharides by oxidation; electron-dense silver deposits are thus formed at the site. Oxidation also serves to re-oxidize reduced osmic acid which would, if not removed, also reduce silver. During fixation of biological specimens with osmic acid, lower oxides of osmium are formed which blacken the cells and are responsible for much of the electron-density of the sections. Treatment of sections with periodic acid re-oxidizes the reduced osmium by converting it to the soluble tetroxides. This results in a decrease in electron-density in the specimen, particularly in the membranes (Silva, 1967).

The development of silver grains along the cell wall is in agreement with the demonstration of polysaccharide components in isolated walls of both Gram-positive and Gram-negative bacteria by Salton (1953). Staining of the cortex is also explicable by reference to its mode of development and to chemical studies on disintegrated spores. It is known that the cortex is secreted between the two membranes of the fore-spore, which develops as an invagination of the cytoplasmic membrane (Fitz-James, I960; Ohye \& Murrell, 1962). The cortex is in close contact with the 'outer' side of the cytoplasmic membrane, which would normally be in contact with the bacterial cell wall and can thus be regarded, in part, as an endogenous cell wall (Warth, Ohye \& Murrell, $1963 a, b$ ). From their chemical studies on disintegrated spores these workers have also suggested that the spore cortex and bacterial cell wall have a similar chemical composition. Their observation that the spore coat and exosporium consist mainly of protein is supported by our observation that membranes of neither were stained with silver grains.

In some previously reported studies the chemical analyses of various fractions of bacteria have been complicated by the fact that these have not always been homogeneous. For example, it was pointed out by Warth et al. $(1963 b)$ that while the analysis of spore-coat preparations by several workers had indicated the presence of small amounts of hexosamine or DPA material, this could be explained by the presence of small amounts of adherent cortical material in their preparations. The advantage of direct staining is that the chemical components can be identified in situ without any undue distortion of the structure. As far as is known this is the first successful application of this method to the demonstration of bacterial carbohydrate in situ.

\section{REFERENCES}

Baillie, A., Thomson, R. O., Batty, I. \& Walker, P. D. (1967). Some preliminary observations on the location of esterases in Bacillus cereus. J. appl. Bact. 30, 3 I 2.

Churg, J., Mautner, W. \& Grisham, E. (I958). Silver impregnation for electron microscopy. $J$. biophys. biochem. Cytol. 4, $84 \mathrm{I}$.

Fitz-James, P. D. (1960). Participation of the cytoplasmic membrane in the growth and spore formation of bacilli. J. biophys. biochem. Cytol. 8, 507 .

Fitz-James, P. D. (I962). Morphology of spore development in Clostridium pectinovorum. J. Bact. 84, 104.

Freeman, J. A. \& Spurlock, B. O. (1962). A new epoxy embedment for electron microscopy. J. Cell Biol. $\mathbf{1 3}, 437$.

Granboulan, P. \& Leduc, E. H. (1967). Ultrastructural cytochemistry of Bacillus subtilis. J. Ultrastruct. Res. 20, $\mathrm{II}$ I.

Gomori, G. (1946). New histochemical test for glycogen and mucin. Am. J. clin. Path. xo, I77. 
Hashimoto, T. \& NAYlor, H. B. (1958). Studies on the fine structure of micro-organisms. II. Electron microscopic studies on sporulation of Clostridium sporogenes. J. Bact. 75, 647.

VAN Iterson, W. \& LeENE, W. (I964a). A cytochemical localization of reductive sites in a Grampositive bacterium. Tellurite reduction in Bacillus subtilis. J. cell Biol. 20, 360 .

VAN ITERSON, W. \& LEENE, W. (1964b). A cytochemical localization of reductive sites in a Gramnegative bacterium. Tellurite reduction in Proteus vulgaris. J. cell Biol. 20, 377.

Jones, D. B. (1957). Nephrotic glomerulonephritis. Am. J. Path. 33, 313.

KaWATA, T., INOUE, T. \& TAKAGI, A. (1963). Electron microscopy of spore formation and germination in Bacillus subtilis. Jap. J. Microbiol. 7, 23.

Kellenberger, E., RYter, A. \& SÉchaud, J. (1958). Electron microscope study of DNA containing plasms. II. Vegetative and mature phage DNA as compared with normal bacterial nucleoids in different physiological states. J. biophys. biochem. Cytol. 4, 67I.

MARINOzZI, V. (196I). Silver impregnation of ultrathin sections for electron microscopy. J. biophys. biochem. Cytol. 9, I2I.

De Martino, C. \& Zamisoni, L. (1967). Silver methanamine stain for electron microscopy. J. Ultrastruct. Res. 19, 273.

Monneron, A. \& Bernhard, W. (1966). Action de certaines enzymes sur des tissues inclus en epon. J. Microscopie 5, 697 .

Nermut, M. V. (I967). The ultrastructure of the cell wall of Bacillus megaterium. J. gen. Microbiol. 49, 503.

Ohye, A. D. \& Murrell., W. G. (1962). Formation and structure of the spore of Bacillus coagulans. J. cell Biol. 14, I I.

Salton, M. R. J. (1953). Studies of the bacterial cell wall. IV. The composition of the cell walls of some Gram-positive and Gram-negative bacteria. Biochim. biophys. Acta ro, 5 I 2.

SedAR, A. W. \& Burde, R. M. (1965a). Localization of the succinic dehydrogenase system in Escherichia coli using combined techniques of cytochemistry and electron microscopy. $J$. cell Biol. 24, 285.

Sedar, A. W. \& Burde, R. M. (1965b). The demonstration of the succinic dehydrogenase system in Bacillus subtilis using tetranitro-blue tetrazolium combined with techniques of electron microscopy. J. cell Biol. 27, 53 .

Short, J. (1968). Silver staining of ultrathin sections of bacteria. Stain Technol. (in the Press).

Silva, M. T. (1967). Electron microscopic studies on the effect of the oxidation of ultrathin sections of Bacillus cereus and Bacillus megaterium. J. Ultrastruct. Res. 18, 345.

Takagi, A., Kawata, T. \& Yamamoto, S. (1960). Electron microscopic studies on ultrathin sections of spores of Clostridium tetani and Clostridium histolyticum with special reference to sporulation and spore germination process. Jap. J. Microbiol. 4, 137.

Thomson, R. O., Walker, P. D. \& Hardy, R. W. (1966). The location of spore and vegetative antigens of Bacillus cereus by means of ferritin-labelled antibodies. Nature, Lond. 2 ro, 760.

Walker, P. D., Baillie, A., Thomson, R. O. \& Batty, I. (I966). The use of ferritin-labelled antibodies in the location of spore and vegetative antigens of Bacillus cereus. J. appl. Bact. 29, 512.

Walker, P. D., Thomson, R. O. \& BaIllie, A. (1967a). The use of ferritin-labelled antibodies in the location of spore and vegetative antigens of Bacillus subtilis. J. appl. Bact. 30, 317.

Walker, P. D., Thomson, R. O. \& Baillie, A. (1967b). Fine structure of Clostridia with special reference to the location of antigens and enzymes. J. appl. Bact. 30, 444.

WARth, A. D., OHYE, D. F. \& Murrell, W. G. (1963a). The composition and structure of bacterial spores. J. cell Biol. 16, 579.

Warth, A. D., Ohye, D. F. \& Murrell, W. G. (1963b). Location and composition of spore mucopeptides in Bacillus species. J. cell Biol. 16, 593.

Young, E. I. (1958). Chemical and morphological changes during sporulation in variants of Bacillus cereus. Thesis, University of Ontario, Canada.

Young, E. I. \& Fitz-JAmes, P. C. (I959 a). Chemical and morphological studies of bacterial spore formation. I. The formation of spores in Bacillus cereus. J. biophys. biochem. Cytol. 6, 467.

Young, E. I. \& FITZ-JAMES, P. C. (I959 $b$ ). Chemical and morphological studies of bacterial spore formation. II. Spore and parasporal protein formation in Bacillus cereus var. alesti. J. biophys. biochem. Cytol. 6, 483 .

Young, E. I. \& Fitz-James, P. C. (1962). Chemical and morphological studies of bacterial spore formation. IV. The development of spore refractility. J. cell Biol. 12, I I5. 
Journal of General Microbiology, Vol. 52, No. 3

Plate I

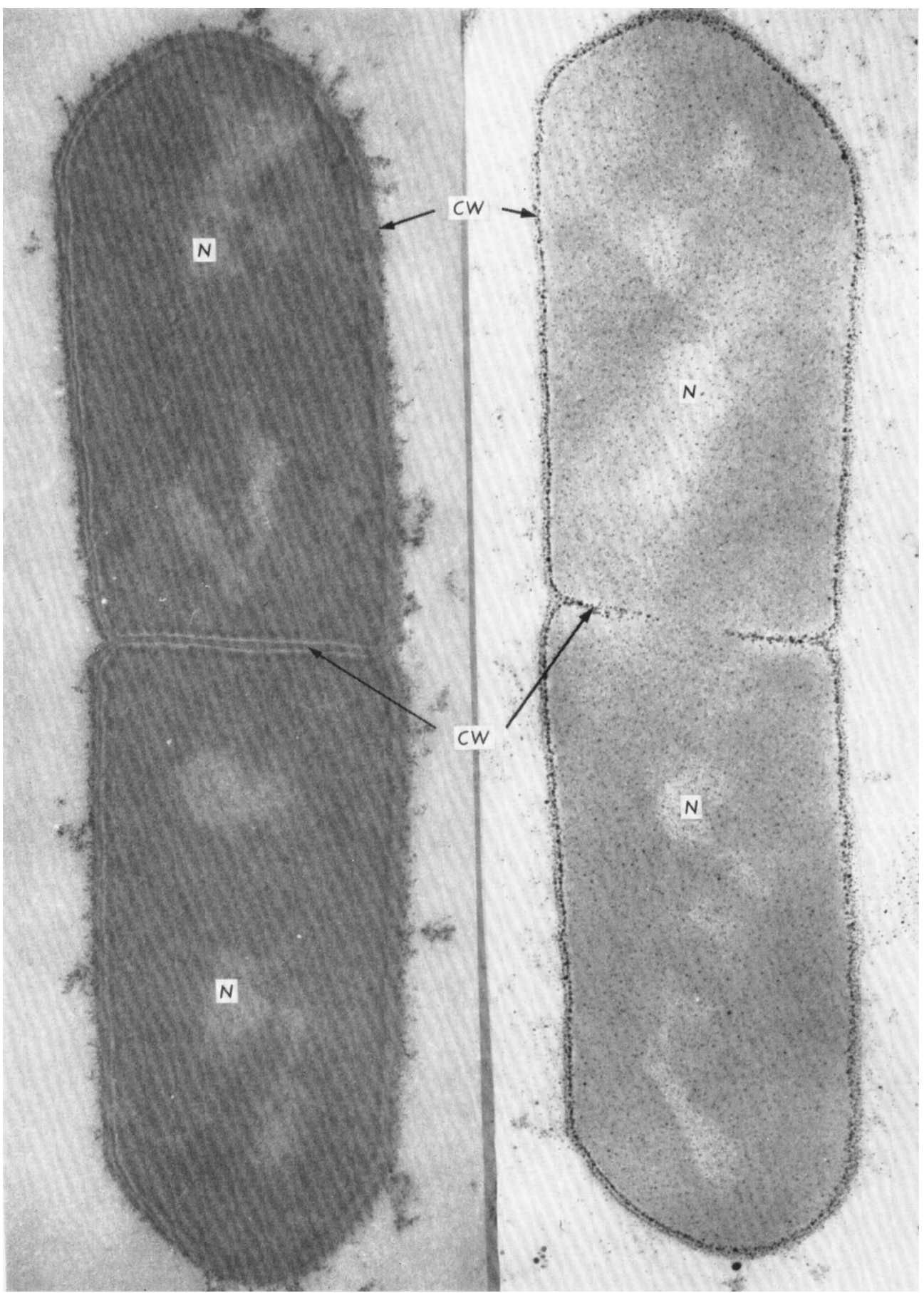

P. D. WALKER AND J. SHORT

(Faciug p. 470) 


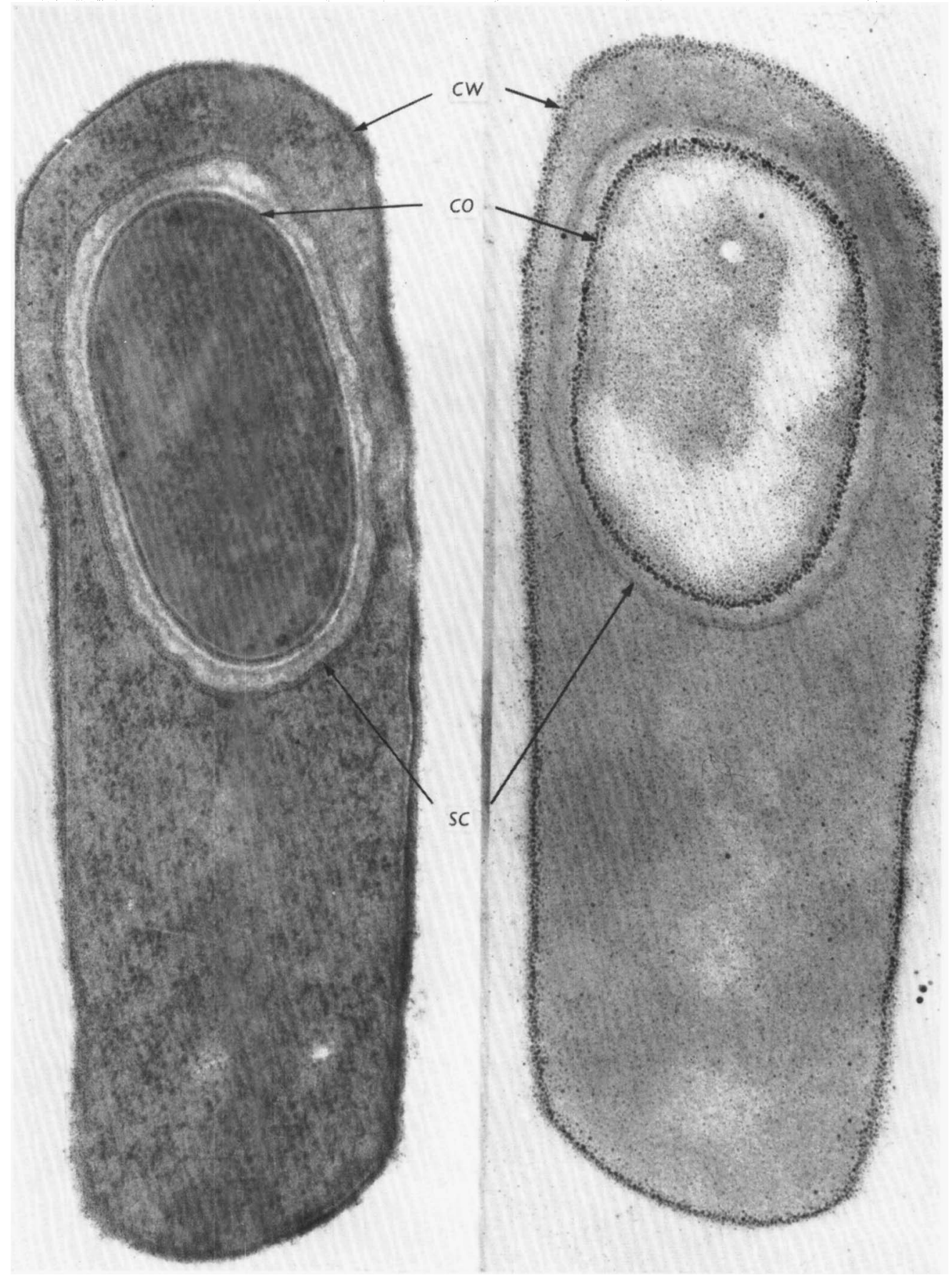

P. D. WALKER AND J. SHORT 

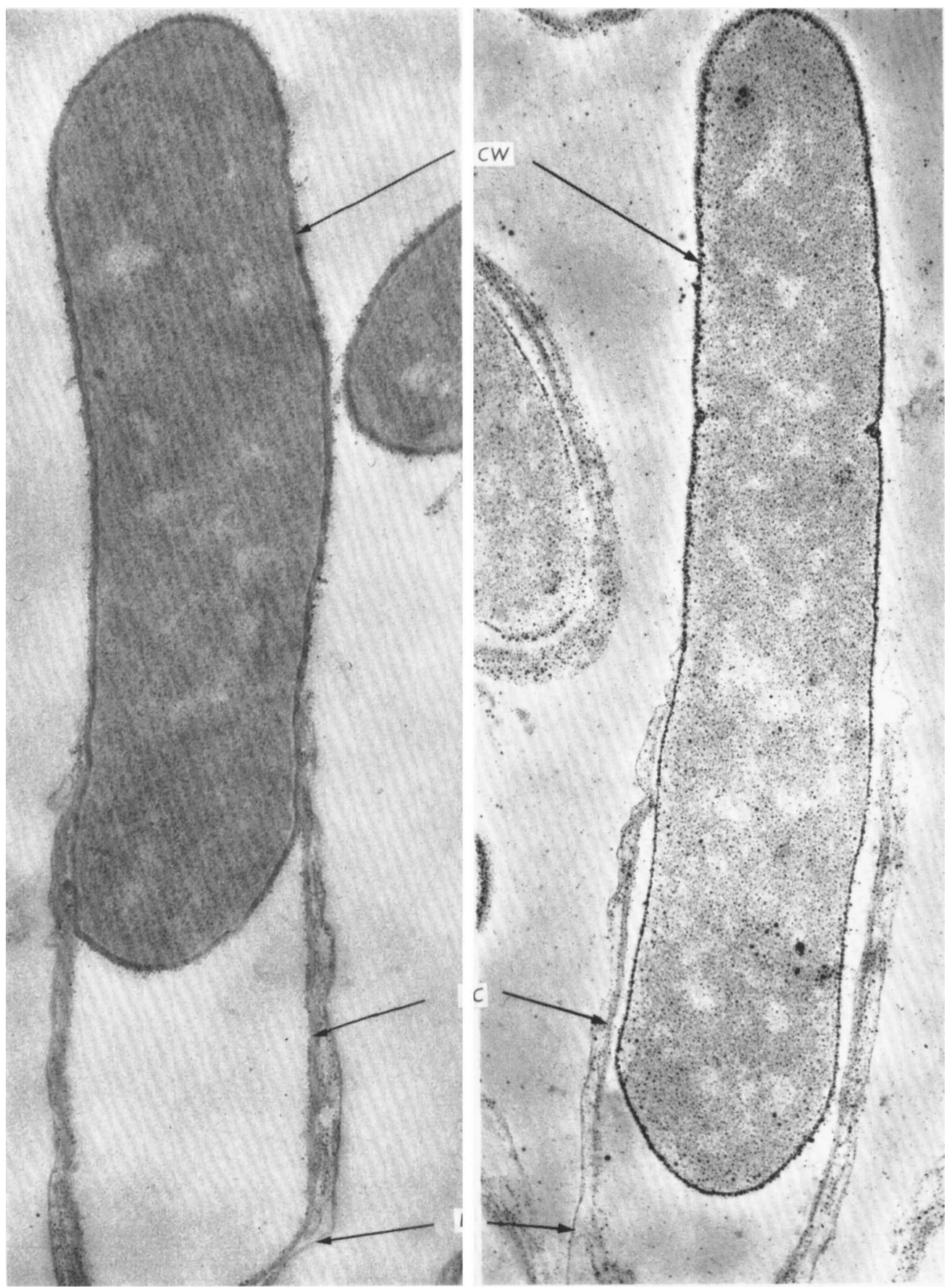

P. D. WALKER AND J. SHORT 
Journal of General Microbiology, Vol. 52, No. 3

Plate 4
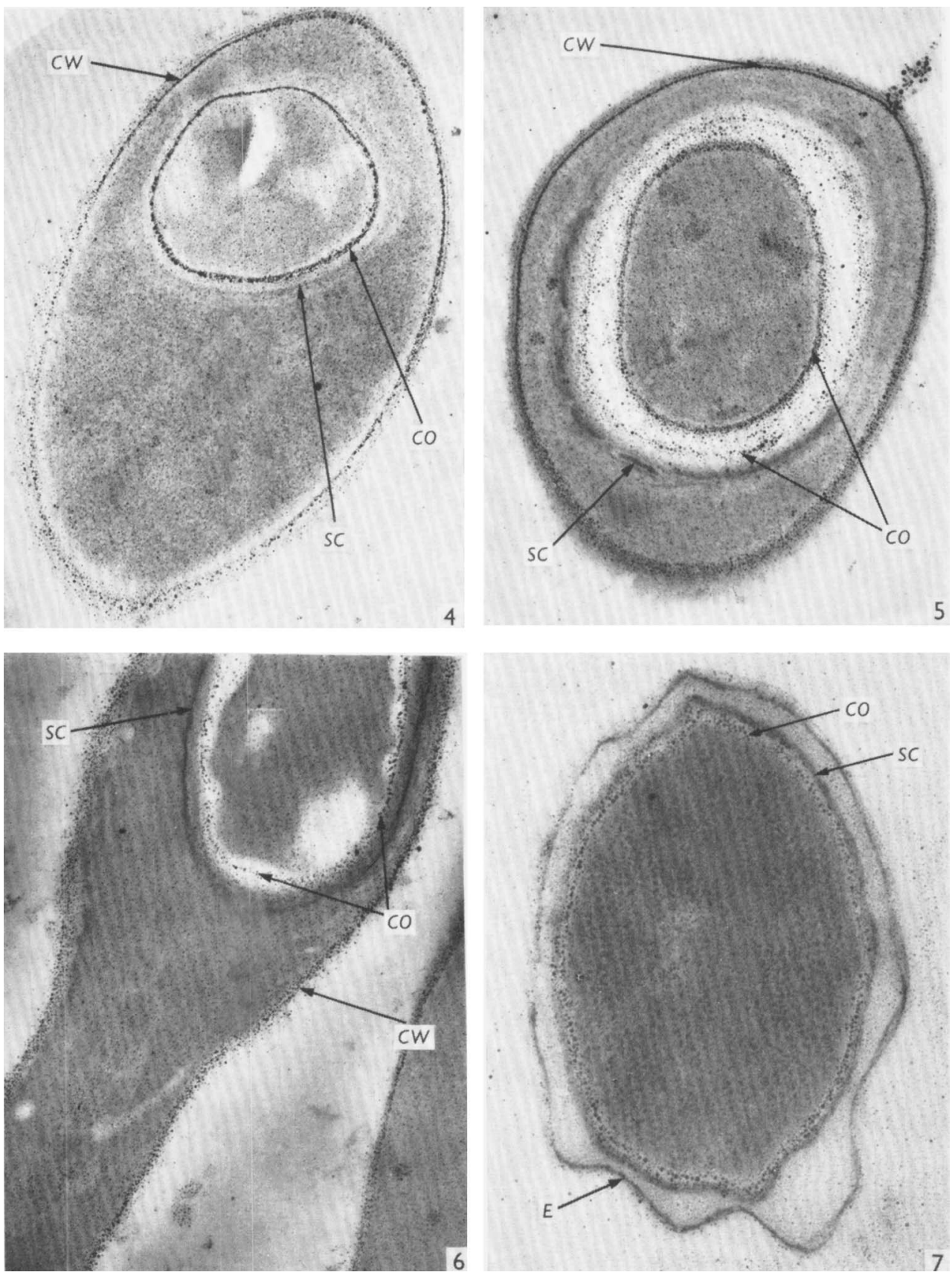

P. D. WALKER AND J. SHORT 


\section{EXPLANATION OF PLATES}

Abbreviations used: $C W=$ cell wall; $C O=$ cortex; $S C=$ spore coat $E=$ exosporium; $N=$ nuclear material.

\section{Plate I}

Fig. I. Section of young vegetative cells of Clostridium bifermentans CNI617 unoxidized (L) and oxidized with periodic acid (R); stained with silver. Silver grains can be seen along the cell wall and developing cross-wall. $\times 65,000$.

\section{Plate 2}

Fig. 2. Section of sporulating cells of C. bifermentans $\mathrm{CN} 1617$ unoxidized (L) and oxidized with periodic acid (R); stained with silver. Deposits of silver are located along the cell wall and cortex, not the spore coat. $\mathrm{L}, \times 60,000 ; \mathrm{R}, \times 76,250$.

\section{Plate 3}

Fig. 3. Section of germinating spore of $C$. bifermentans CN I 6I7, showing outgrowth after 1 hr incubation unoxidized, L; and oxidized with periodic acid, $\mathrm{R}$; stained with silver. Deposits of silver grains are seen along the cell wall of developing vegetative cell, but not along the spore coat or exosporium. L, $\times 54,400 ; \mathrm{R}, \times 46,000$.

\section{Plate 4}

Figs. 4, 5. Section of sporulating cells of $C$. botulinum type $\mathrm{C} \mathrm{CN} 4946$ after oxidation and staining with silver. Deposits of silver are arranged along the vegetative cell wall and along the cortex. Fig. 4, $\times 45,750$; fig. $5, \times 61,000$.

Fig. 6. Section of sporulating cells of $C$. sporogenes L206 after oxidation and staining with silver. Deposits of silver are evident along the vegetative cell wall and cortex, but not the spore coat. $\times 45,750$.

Fig. 7. Section of germinating spore of Bacillus cereus var. terminalis ( 5 min. incubation), after oxidation and staining with silver. Deposits of silver are evident along cortex and developing vegetative cell wall. $\times 93,500$. 